\title{
Carbon Capture and Storage - Solidification and Storage of Carbon Dioxide Captured on Ships
}

\section{Peilin Zhou and Haibin Wang*}

Department of Naval Architecture and Marine Engineering, University of Strathclyde, G4 0LZ, Glasgow, UK

\begin{abstract}
To meet the International Maritime Organization (IMO) target of $20 \%$ reduction of $\mathrm{CO}_{2}$ emissions from marine activities by 2020, application of Carbon Capture and Storage (CCS) on ships is considered as an effective way to mitigate $\mathrm{CO}_{2}$ emissions while other low carbon shipping technologies being developed. Literature reviews on CCS methods for onshore applications indicate that the current CCS technologies could not be implemented on boards directly due to various limitations on ships. A novel chemical $\mathrm{CO}_{2}$ absorption and solidification method for $\mathrm{CO}_{2}$ storage on-board is proposed, presented and analyzed. Technical feasibility with explanation of principles and cost assessment are carried out for a case ship with a comparison to a conventional CCS method. The paper also presents results obtained from laboratory experiment including factors that affect the absorption. Theoretical study and laboratory experiment illustrate the proposed $\mathrm{CO}_{2}$ solidification method is a promising, cost effective and feasible method for $\mathrm{CO}_{2}$ emissions reduction on ships.
\end{abstract}

\section{Keywords}

Emissions reduction; carbon capture, solidification and storage; chemical absorption; environment protection.

\footnotetext{
${ }^{*}$ Corresponding author at: Department of Naval Architecture and Marine Engineering, Henry Dyer Building, 100 Montrose Street, University of Strathclyde, G4 0LZ, Glasgow, UK. Tel.: +44 (0)141 548 3344; fax: +44 (0)141 552 2879. E-mail address: haibin.wang.100@strath.ac.uk
} 


\section{Introduction}

Climate change has become a popular topic simply because it leads the melting glaciers, rising sea levels and the extinction of endangered species. It is well-known that greenhouse gases (GHG) are the cause of the climate change which is mainly contributed by the carbon dioxide (Houghton, 2004). According to IPCC report, the current $\mathrm{CO}_{2}$ concentration in the atmosphere is increased by $100 \mathrm{ppm}$ which is about $34 \%$ increment compared with the pre-industrial level (Ronger et al., 2007). Fig. 1 presents the growing of $\mathrm{CO}_{2}$ emissions from 2000 to 2009 (Boden et al., 2010). Although the emissions are a little bit declined from 2008 to 2009, the tendency of the curve is obviously climbing. For the global economy, international shipping have an immeasurable effect as it is the most effective way for large quantity and long distance transportation of international trade. Referring to the report of Second IMO GHG Study 2009, international shipping is estimated to have 870 million tones $\mathrm{CO}_{2}$ emitted in 2007 which is about $2.7 \%$ of the global $\mathrm{CO}_{2}$ emissions (Buhaug et al., 2009). There are numbers of methods to reduce the ship GHG emissions. EEDI, EEOI and SEEMP stipulated by IMO are focusing on increasing the energy efficiency. With high energy efficiency, the fuel consumed will be reduced so that the $\mathrm{CO}_{2}$ generated will be decreased. EEDI, EEOI and SEEMP regulations are proposed to be entered into force on 2013 with an aim to reduce about 180 million tons of $\mathrm{CO}_{2}$ emissions from international shipping annually by 2020 . It is about $20 \%$ of the current emissions level. Thus, so many projects emerge with a target of $20 \%$ reduction of $\mathrm{CO}_{2}$ emissions.

\section{-- Insert Figure 1 here --}

Fig. 1 Tendency of $\mathrm{CO}_{2}$ emissions from 2000 to 2009

$\mathrm{CCS}$ is an effective way to mitigate and even eliminate the effect of global warming caused by $\mathrm{CO}_{2}$ emissions. It is now only used on shore based power plants and industrial processes (Global Carbon 
Capture and Storage Institute). Fig. 2 presents three general ways of CCS that are available for onshore application. The principles of pre-combustion method are to remove carbon component from the fossil fuel priory to its combustion. Oxy-fuel capture method is to burn the fossil fuel with pure oxygen rather than oxygen in air so that only $\mathrm{CO}_{2}$ and water vapor are produced after combustion and $\mathrm{CO}_{2}$ can be easily captured by condensing the flue gases. Post-combustion capture method is to have $\mathrm{CO}_{2}$ captured from the flue gases after the combustion of the fossil fuel.

\section{-- Insert Figure 2 here --}

Fig. 2 General carbon capture methods

Although these methods could help capture carbon from fuel oil, mechanically installation of the systems on ships will bring great impacts on shipping performance. For instance, additional power consumption will increase fuel consumption, more space taken leads a reduction of cargo transported and storage of $\mathrm{CO}_{2}$ on ships in a form of gas or liquid state is difficult and unsafe. No matter what kind of method is considered, the impacts on shipping performance should be minimized.

A novel carbon capture method is proposed in order to reduce the power requirement, save spaces on board and avoid $\mathrm{CO}_{2}$ storage in a gas or liquid form on ships. This method applies two chemical processes and a physical step to absorb $\mathrm{CO}_{2}$ from exhaust gases, precipitate the $\mathrm{CO}_{3}{ }^{-}$ion and separate $\mathrm{CaCO}_{3}$ from the absorption solution on ship board.

In this study, the results obtained from laboratory experiment are extended to apply on a case ship. An economical assessment is presented by comparing the chemical processes for carbon solidification (CPCS) with the $\mathrm{CO}_{2}$ compression and liquefaction method used commonly for the case ship, together with the results obtained from the experiment. 


\section{Chemical processes for carbon dioxide solidification}

There are two chemical processes involved which include $\mathrm{CO}_{2}$ absorption and $\mathrm{CO}_{3}{ }^{-}$ions precipitation. The reactions related to these two processes are shown in equation (1) and (2) (Pflug et al., 1957; Mahmoudkhani and Keith, 2009):

$\mathrm{CO}_{2}(\mathrm{~g})+2 \mathrm{NaOH}(\mathrm{l})=\mathrm{Na}_{2} \mathrm{CO}_{3}(\mathrm{l})+\mathrm{H}_{2} \mathrm{O}(\mathrm{l})-\Delta \mathrm{H}_{1}$

$\mathrm{Na}_{2} \mathrm{CO}_{3}(\mathrm{l})+\mathrm{Ca}(\mathrm{OH})_{2}(\mathrm{~s})=\mathrm{CaCO}_{3} \downarrow(\mathrm{s})+2 \mathrm{NaOH}(\mathrm{l})-\Delta \mathrm{H}_{2}$

In the first reaction, the carbon dioxide is absorbed by sodium hydroxide $(\mathrm{NaOH}$, caustic soda). Sodium hydroxide reacts with acid gases, such as $\mathrm{CO}_{2}, \mathrm{SOx}$ and $\mathrm{NOx}$, is a natural process. The products from this reaction are sodium carbonate $\left(\mathrm{Na}_{2} \mathrm{CO}_{3}\right.$, washing soda) and water. $\mathrm{Na}_{2} \mathrm{CO}_{3}$ is a relative stable compound so that $\mathrm{CO}_{2}$ can be stored as $\mathrm{CO}_{3}{ }^{-}$ions in the $\mathrm{Na}_{2} \mathrm{CO}_{3}$ solution. After the absorption reaction, the $\mathrm{Na}_{2} \mathrm{CO}_{3}$ solution will react with calcium oxide $(\mathrm{CaO}$, quicklime $)$ and water. Finally, the precipitated calcium carbonate $\left(\mathrm{CaCO}_{3}\right.$, limestone) is produced, as shown in reaction (2). The $\mathrm{CO}_{3}{ }^{-}$ions are precipitated in the form of $\mathrm{CaCO}_{3}$ compound. After filtering, washing and drying processes, the powders of precipitated calcium carbonate will be obtained which can be stored safely on-board and unloaded at the destination of a voyage. The reaction presented in equation (3), generating calcium hydroxide $\left(\mathrm{Ca}(\mathrm{OH})_{2}\right.$, hydrate lime), is an internal reaction of reaction (2). It is an exothermal reaction where reaction heat can be recovered and reused (Souto et al., 2008).

$\mathrm{CaO}(\mathrm{s})+\mathrm{H}_{2} \mathrm{O}(\mathrm{l})=\mathrm{Ca}(\mathrm{OH})_{2}(\mathrm{~s})-\Delta \mathrm{H}_{3}$

The heat released during three reactions is $109.4,5.3$ and $65 \mathrm{~kJ}$ per mol $\mathrm{CO}_{2}$ respectively (Mahmoudkhani and Keith, 2009). While dissolving $\mathrm{NaOH}$ into water, there are heat released as well which is $35.82 \mathrm{~kJ}$ per mol NaOH (Japan Soda Industry Association, 2006).

Based on these reactions, $\mathrm{CO}_{2}$ from the exhaust gases are eventually captured and stored in a solid form. Referring to the conservation of mass, the masses of reactants are equal to the masses of the 
products. As masses are related to molecule masses and molar numbers, the relationships between different substances are shown as following equation:

$\mathrm{m}_{1} / \mathrm{m}_{2}=\left(\mathrm{n}_{1} \times \mathrm{M}_{1}\right) /\left(\mathrm{n}_{2} \times \mathrm{M}_{2}\right)$

Where:

$\mathrm{m}_{1}=$ total mass of substance 1 (ton);

$\mathrm{m}_{2}=$ total mass of substance 2 (ton);

$\mathrm{n}_{1}=$ molar number of substance $1(\mathrm{~mol})$;

$\mathrm{n}_{2}=$ molar number of substance $2(\mathrm{~mol})$;

$\mathrm{M}_{1}=$ molar mass of substance $1(\mathrm{~kg} / \mathrm{mol})$;

$\mathrm{M}_{2}=$ molar mass of substance $2(\mathrm{~kg} / \mathrm{mol})$.

This relationship will be used to derive the masses of different chemical substances involved in the reactions.

As the $\mathrm{CaCO}_{3}$ is generated from the solution, what obtained from reactions is $\mathrm{CaCO}_{3}$ mud which is a mixture of $\mathrm{NaOH}$ solution and $\mathrm{CaCO}_{3}$ (Metso, 2011). To separate the sediment from the solution, a filtration process is applied. After filtration and drying, solid sediment will be available for storing on ship.

Other than being able to retrofit on existing ships, there are many advantages when applying CPCS comparing to $\mathrm{CO}_{2}$ compression and liquefaction for shipboard application. The final product precipitated $\mathrm{CaCO}_{3}$ from the solidification processes can be used by many applications in industry, for instance, paper making, construction and plastic industries. Due to a large quantity of precipitated $\mathrm{CaCO}_{3}$ produced, profits made by selling the product could be considerable. When storing liquefied $\mathrm{CO}_{2}$ on board, issues like ship stability, spaces occupied and high requirement for storage tank due to the instability of liquefied $\mathrm{CO}_{2}$ are serious problems. With the application of CPCS, all these 
problems will be solved. These advantages will be presented in detail in the section of case ship study.

\section{Experiment and results}

Based on the principles of the solidification processes introduced above, two steps of experiment are designed: chemical absorption and precipitation, and physical filtration. In the chemical processes, pure $\mathrm{CO}_{2}$ is used.

A flow chart of the experimental rig is shown in Fig. 3. Fig. 4 is a picture of the experiment rig. The flow of $\mathrm{CO}_{2}$ gas contained in a $\mathrm{CO}_{2}$ bottle is controlled by a regulator. The gas is piped into $\mathrm{NaOH}$ solution inside a measuring cylinder. A diffuser is used to increase the contact area between the gas and solution by generating gas bubbles. Inside the measuring cylinder, the gas is absorbed by the solution. After the absorption, $\mathrm{CaO}$ powders are added into the measuring cylinder so that the $\mathrm{CO}_{3}{ }^{-}$ ions can be precipitated.

-- Insert Figure 3 here --

Fig. 3 Schematic of the experiment systems

After the precipitation, the mixture of sediment and solution goes through a funnel with filter paper where the sediment and solution are separated. After the filtration, the sediment obtained will be dried for further measurement.

-- Insert Figure 4 here --

Fig. 4 Pictures of experiment rig

Table 1 presents the results of gas absorption rate, $\mathrm{NaOH}$ regeneration rate and $\mathrm{CaCO}_{3}$ filtration efficiency achieved from experiment. The $\mathrm{CO}_{2}$ absorption rate is a ratio between gases absorbed and that gas fed in. The regeneration rate of $\mathrm{NaOH}$ is defined as the ratio of $\mathrm{NaOH}$ regenerated and that 
initially supplied. The $\mathrm{CaCO}_{3}$ filtration efficiency is determined by ratio of $\mathrm{CaCO}_{3}$ separated to theoretical formatted from reaction.

Table 1 Experiment results

-- Insert Table 1 here --

From the table, the gas absorption rate is nearly $68 \%$ but it is only the rate under laboratory conditions. For an industrial application, a much better mixing process of gas and solution can be obtained by using a mechanical stirrer so that the absorption rate will be higher than that under laboratory conditions. Another factor will be considered in the industrial processes is the purity and concentration of $\mathrm{CO}_{2}$ gas. Due to the impurities in exhaust gases in a practical application, further treatments may be required for purification so the absorption rate will be varied.

Whatman grade 589/3 qualitative filtration papers are used for the separation of $\mathrm{NaOH}$ solution and $\mathrm{CaCO}_{3}$ in the experiment. This type of filter paper is suitable for high retention of fine particles and have an excellent resistance from strong alkali solution. The filter papers with a diameter of $125 \mathrm{~mm}$ are selected to match the funnel. The particle size of $\mathrm{CaCO}_{3}$ ranges from 1 to $3 \mu \mathrm{m}$ and pore size of filter papers is less than $2 \mu \mathrm{m}$ which is the smallest one for laboratory use. The small pore size does not only lead a long period of filtration processes but also result in a small amount of $\mathrm{CaCO}_{3}$ slipping through the filter. The $\mathrm{CaCO}_{3}$ filtration efficiency is expected to be much higher in practical application because industrial filtration method, such as pressure disc filter or centrifugal separation. To simplify the study, the filtration efficiency used in the case ship study is taken as $100 \%$.

In order to estimate the $\mathrm{CO}_{2}$ absorption rate, four parameters were examined during the experiment: gas input flow rate, change of absorption cylinder diameter with fixed volume of solution, change of absorption cylinder diameter with solution column height unchanged and change of solution column height with the same diameter of cylinder. 


\subsection{Impact of gas flow rate on absorption rate}

To find out effect of the gas flow rate on the $\mathrm{CO}_{2}$ absorption rate, three runs of experiment with different gas flow rates are conducted. The selected gas flow rates are 1, 2 and $3 \mathrm{~L} / \mathrm{min}$. The selection of gas flow rate is restricted by the experiment equipment because higher flow rate will lead to an unstable pipe connection and even disconnected. To ensure the accuracy of reading on flow meter, only integer scales are selected for comparison. For these three sets, the same quantity solution is used with the solution column height of $30 \mathrm{~cm}$. The diameter of the measuring cylinder is $6 \mathrm{~cm}$. The results are presented in Table 2 and Fig. 5.

Table 2 Change of absorption rate with gas input flow rate

-- Insert Table 2 here --

-- Insert Figure 5 here --

Fig. $5 \mathrm{CO}_{2}$ absorption rate vs. gas flow rate

According to the experimental results, the $\mathrm{CO}_{2}$ absorption rate increases as the input gas flow rate decreases. The reason being a small gas flow rate allows more time for contact of the gas and the solution. As the gas flow increases, the amount of $\mathrm{CO}_{2}$ slipped from the absorption process will be increased. However, the reduction rate is only $2.7 \%$ when the gas flow rate is increased from 1 $\mathrm{L} / \mathrm{min}$ to $3 \mathrm{~L} / \mathrm{min}$. Hence, it is concluded that the flow rate has no significant effect on absorption rate under the conditions used in the experiment.

\subsection{Impact of cylinder diameters on absorption rate with fixed volume of solution}

Table 3 Changing of absorption rate with container diameters (solution quantity unchanged)

-- Insert Table 3 here --

-- Insert Figure 6 here --

Fig. 6 Effect of container diameter on gas absorption rate with unchanged solution quantity

According to Table 3 and Fig. 6, the absorption rate is decreased while the container has a larger diameter. It is easy to find that container with a large diameter leads a short time for $\mathrm{CO}_{2}$ gas 
contacting with the solution. It is because column height is reduced as the cylinder diameter is increased when the volumes of the solution are fixed. When the diameter is changed from 6 to $8 \mathrm{~cm}$, less than $3 \%$ of the gas are released and wasted. The percentage grows to $6.64 \%$ when the diameter is increased from 8 to $10 \mathrm{~cm}$. From the curve above, it is obviously that declining of the curve is faster along the $\mathrm{X}$ axis. Hence, the absorption rate will be increasingly reduced when enlarging the diameter. On the contrary, narrowing the diameter will lead a greatly increasing on absorbing gas when changing diameter of cylinder without changing volume of the solution. It is a feasible and effective way of enhancing $\mathrm{CO}_{2}$ absorption rate by increasing the contact rate between gas and solution.

\subsection{Impact of cylinder diameters on absorption rate with solution column height unchanged}

According to the result above, a better mixing and long contact time between gas and solution will bring a higher absorption rate of $\mathrm{CO}_{2}$ gas. Results in Table 4 and Fig. 7 show the effect of change of the cylinder diameter (cross-section area) on absorption rate with fixed height of solution column height.

Table 4 Changing of absorption rate with container diameters (same solution column height)

-- Insert Table 4 here --

-- Insert Figure 7 here --

Fig. 7 Effect of container diameter on gas absorption rate with fixed solution height

Results shows when the cylinder diameter varies from 6 to $10 \mathrm{~cm}$ with the same column height of $10.5 \mathrm{~cm}$, the highest absorption rate takes place when the diameter is $10 \mathrm{~cm}$. When the diameter is changed from 6 to $8 \mathrm{~cm}$, the absorption rate is increased by $9.7 \%$. A further increase in the diameter from $8 \mathrm{~cm}$ to $10 \mathrm{~cm}$, the rate is increased only by $1.91 \%$. It is understandable that the absorption rate will be increasing when the solution column cross-section area is increased. For the given test rig set up, the results indicate that a too large cross-section area does not help to increase the absorption rate 
much. This could be because the diffuser size is not increased as the diameter increases. Hence, when the cross-section is too large the gas bubble could not reach to the edge area of the cylinder. This means there is room for test rig optimization to achieve the best match of solution column cross-section area, diffuser size and column height.

\subsection{Impact of column height on absorption rate with a fixed cylinder diameter}

Table 5 Change of absorption rate with solution column heights (fixed container diameter)

-- Insert Table 5 here --

-- Insert Figure 8 here --

Fig. 8 Effect of solution column height on gas absorption rate with same cylinder diameter

According to Table 5 and Fig. 8 above, the absorption rate is increased while the height of the solution column is increased. This is because as the solution height increased, the path of gas are increased, resulting in an increase in the contacting time between the gas and solution. Hence, more gas will be absorbed. When the height is increased from 10.5 to $18 \mathrm{~cm}$, the absorption rate is raised by $16.09 \%$. The rate grows only $5.02 \%$ when the solution column is changed from 18 to $30 \mathrm{~cm}$. It is because with small solution column height, the path of gas is too short to have a good contact with solution. When the solution height increased, the change will be significant at the beginning and then will be very slightly. This indicates that there is an optimal match between the column height and gas supply rate.

\section{Case Ship Study}

Nowadays, there are two technologies used onshore for the storage and transportation of $\mathrm{CO}_{2}$ captured, i.e. compressed $\mathrm{CO}_{2}$ and liquefied $\mathrm{CO}_{2}$. For pipeline transportation, compressed $\mathrm{CO}_{2}$ is a preferred option (Ciferno et al., 2010; Witkowski and Majkut, 2012). If captured $\mathrm{CO}_{2}$ is transported by a ship, both compressed $\mathrm{CO}_{2}$ and liquefied $\mathrm{CO}_{2}$ technologies can be used, where the latter is achieved by a combination of increased pressure and reduced temperature (Bert et al., 2005). 
Currently, only the liquefied $\mathrm{CO}_{2}$ method has been used for ship transportation (Aspelund et al., 2006) due to the factor of some 580 times of volume reduction from gas form $\mathrm{CO}_{2}$ to liquid form $\mathrm{CO}_{2}$.

There are some technical challenges in storing and transporting $\mathrm{CO}_{2}$ in liquid form on ships.

In addition to the requirement of low temperature and high pressure, liquefied $\mathrm{CO}_{2}$ has a triple phase point. The triple phase point is an unstable state of $\mathrm{CO}_{2}$ which means a phase change of $\mathrm{CO}_{2}$ may take place from liquid state to solid or gas without a change in temperature or pressure. Storage of $\mathrm{CO}_{2}$ liquid also has special requirements on the materials of storage tanks in order to cope with high pressure and low temperature. It is essential to make sure that there is no water or moisture contained in liquefied $\mathrm{CO}_{2}$ to prevent corrosion of tank materials. Compared with the method of CPCS, the volume taken by liquefied $\mathrm{CO}_{2}$ is $3 \%$ more than that of $\mathrm{CaCO}_{3}$ (EIGA, 2010). In addition, carrying liquefied $\mathrm{CO}_{2}$ causes a ship stability problem - sloshing, due to its viscosity is about $1 / 3$ of water (Wischnewski; ITTC, 2011). In summary, in a comparison with $\mathrm{CO}_{2}$ liquid, storing solid $\mathrm{CO}_{2}$ in the form of $\mathrm{CaCO}_{3}$ on ships has the following advantages:
a. $\mathrm{CaCO}_{3}$ can be reused or land disposal;
b. No particular requirements on storage tank materials;
c. No corrosion problems;
d. Less volume taken;
e. No impact on ship stability.

Other than the above ship operational and $\mathrm{CO}_{2}$ storage advantages, a case study on a selected ship indicates that applying CPCS on ships will bring an economical profit by selling the by-products of CPCS. The following section presents a feasibility study of applying CPCS on the case ship. 
The specifications of the case ship are listed in Table 6, along with the details of voyage of the vessel. Since the power output of auxiliary alternators is only about $8.4 \%$ of the main engine power, fuel consumption and $\mathrm{CO}_{2}$ emissions of the auxiliary engines are not considered in the case ships study.

Table 6 Specifications of the case ship

-- Insert Table 6 here --

a: Sources of data: Significant Ships of 2011: Hyundai Trust.

\subsection{Cost estimation of CPCS}

\subsubsection{Total $\mathrm{CO}_{2}$ generated during a voyage}

According to the project guide of the selected engine and fuel type used, the gas flow rate of $\mathrm{CO}_{2}$ emissions can be estimated as equation (5):

$$
\begin{aligned}
\text { 1. } & \quad . \mathrm{SFO} \times \mathrm{P} \times \mathrm{SFOC} \\
= & 3.021 \times 18,660 \times 174 \times 1000 / 3600 \\
= & 2.72 \mathrm{~kg} / \mathrm{s}
\end{aligned}
$$

Where:

$r_{\ldots}=$ mass of $\mathrm{CO}_{2}$ in exhaust gas (ton);

$\mathrm{SFOC}=$ specific fuel oil consumption $(\mathrm{g} / \mathrm{kWh})$

$\mathrm{P}=$ power output of main engine $(\mathrm{kW})$;

$\mathrm{C}_{\mathrm{HSFO}}=$ carbon factor of HSFO (MEPC, 2010).

With this flow rate of $\mathrm{CO}_{2}$, the total $\mathrm{CO}_{2}$ generated during a voyage (16 days) is $3,766.54$ ton.

\subsubsection{Exhaust gas by-pass into CPCS system}

Based on the IMO target of $20 \% \mathrm{CO}_{2}$ emissions reduction by 2020 , the CPCS system will be designed to absorb and store $20 \%$ of $\mathrm{CO} 2$ emitted from the engine of the case ship, i.e. 753.31 ton of 
$\mathrm{CO}_{2}$. According to the experiment results, the average $\mathrm{CO}_{2}$ absorption rate is $67.85 \%$. To achieve $20 \%$ reduction of $\mathrm{CO}_{2}$ emissions, the amount of exhaust gases by-passed to the CPCS system can be derived with equation (6):

$$
\begin{aligned}
\mathrm{R}_{\text {by-pass }} & =\mathrm{R}_{\text {target }} / \mathrm{R}_{1} \\
& =20 \% / 67.85 \% \\
& =29.48 \%
\end{aligned}
$$

Where:

$\mathrm{R}_{\text {by-pass }}=$ percentage of exhausted gas by-pass into the CPCS system;

$\mathrm{R}_{\text {target }}=$ targeted $\mathrm{CO}_{2}$ reduction required by IMO regulations;

$\mathrm{R}_{1}=$ absorption rate of $\mathrm{CO}_{2}$.

According to the above estimation, there is about $30 \%$ of exhaust gas should be fed into the CPCS system in order to achieve the target of $20 \% \mathrm{CO}_{2}$ reductions from the main engine exhaust gas. The mass flow rate of $\mathrm{CO}_{2}$ fed into the CPCS can be derived: $2.72 \times 29.48 \%=0.80 \mathrm{~kg} / \mathrm{s}$. The quantity of $\mathrm{CO}_{2}$ bypassed per voyage is 1,110 ton.

\subsubsection{Initial quantities of chemical substances required}

The quantities of all chemical substances involved in the reaction can be derived by applying the equation (4) in conjunction with the equation (1), (2) and (3). Thus, the quantities of caustic soda $(\mathrm{NaOH})$ and quicklime $(\mathrm{CaO})$ required per voyage are 86 ton and 959 ton, respectively. The limestone $\mathrm{CaCO}_{3}$ finally produced per voyage is 1,712 ton.

\subsubsection{Consumption of $\mathrm{NaOH}$ by CPCS system}

In the CPCS system, $\mathrm{NaOH}$ solution will be regenerated after the causticizing reaction. For the case ship, the $\mathrm{NaOH}$ is assumed to be replenished on a daily basis. Since its regeneration rate is $85.37 \%$ 
according to the experiment results, the daily consumption of $\mathrm{NaOH}$ can be calculated by the following equation:

$$
\begin{aligned}
\mathrm{m}_{\text {refilled }} & =\mathrm{m}_{\text {system }} \times\left(1-\mathrm{R}_{2}\right) \\
& =85.60 \times(1-85.37 \%) \\
& =12.52 \text { ton } / \text { day }
\end{aligned}
$$

Where:

$$
\begin{aligned}
& \mathrm{m}_{\text {refilled }}=\text { daily consumption of } \mathrm{NaOH} \text { (ton); } \\
& \mathrm{m}_{\text {system }}=\text { the theoretical quantity of } \mathrm{NaOH} \text { needed by system (ton); } \\
& \mathrm{R}_{2}=\text { regeneration rate of } \mathrm{NaOH} .
\end{aligned}
$$

The total $\mathrm{NaOH}$ consumed during a voyage can be derived as following:

$$
\begin{aligned}
\mathrm{m}_{\text {total }} & =\mathrm{m}_{\text {refilled }} \times \mathrm{t} \\
& =12.52 \times 16 \\
& =200.34 \text { ton }
\end{aligned}
$$

Where:

$$
\begin{aligned}
& \mathrm{m}_{\mathrm{total}}=\text { total } \mathrm{NaOH} \text { required during a voyage (ton); } \\
& \mathrm{t}=\text { duration of a voyage (days); }
\end{aligned}
$$

\subsubsection{Operational cost of CPCS system}

Operational cost of the CPCS is made of 3 components, i.e. cost of chemicals consumed; cost of fuel operating the CPCS and cost of cargo lost penalty due to space taken by the chemical reactant and CPCS product.

\subsubsection{Cost estimation of chemical substances}

Table 7 presents the quantities of chemicals consumed and their unit prices. 
Table 7 Quantities of substances consumption and costs

-- Insert Table 7 here --

a: Sources of data: Prices achieved from Alibaba.com.

\subsubsection{Energy consumption and fuel costs}

The energy consumed for CPCS process includes energy required for $\mathrm{CO}_{2}$ separation from the engine exhaust gas; energy for $\mathrm{CO}_{2}$ gas and chemical solutions' transfer through the CPCS system; and energy used for handling and storing solid chemicals and end product of $\mathrm{CPCS}\left(\mathrm{CaCO}_{3}\right)$ on ships. Since the energy consumed in handling solids materials are much smaller compared with that in $\mathrm{CO}_{2}$ gas separation and transportation, the energy consumed for solid materials handling is ignored in estimating the system energy consumption.

The power required by gas separation is due to the application of membrane device which is about $0.5 \mathrm{MJ} / \mathrm{kg} \mathrm{CO} 2$ separated (Barbieri et al., 2011). Thus, the energy consumption by the membrane system can be obtained as the following:

$$
\begin{aligned}
P_{M} & =i \ldots \ldots l t \\
& =0.5 \times 10^{3} \times 3766.54 \times 10^{3} \times 29.48 \% /(16 \times 24 \times 3600) \\
& =401.59 \mathrm{~kW}
\end{aligned}
$$

Where:

$P_{M}=$ power required by membrane device $(\mathrm{kW})$;

$\therefore=$ energy required for $\mathrm{CO}_{2}$ separation $(\mathrm{kJ} / \mathrm{kg} \mathrm{CO} 2)$;

$\mathrm{m}_{\mathrm{CO}_{2}}=$ mass of $\mathrm{CO}_{2}$ separated $(\mathrm{kg})$;

$\mathrm{t}=$ operation time of membrane device $(\mathrm{s})$.

$\mathrm{CO}_{2}$ gas pumps (blowers) are used to feed the $\mathrm{CO}_{2}$ gas after the separation unit to pass through the CPCS. The solution height of the reaction tank designed is about 6.44 meter. The blowers should provide enough pressure to feed gas into the bottom of the tank. Other than head loss due to solution 
height in tank, there are friction loss and fitting loss for $\mathrm{CO}_{2}$ to go through the duct system. Assuming the diameter and the length of the duct from the outlet of membrane device to reaction tank are $1 \mathrm{~m}$ and $10 \mathrm{~m}$ respectively and there are one baffler and two $90^{\circ}$ bends along the system. The pressure drops due to friction and fitting estimated at about 0.99 Pa (Massey and Ward-Smith, 2012). The power required for gas input can be obtained with equation (10):

$$
\begin{aligned}
P_{B} & =r_{\ldots 2} \quad-/ \rho_{\mathrm{CO}_{2}} \\
& =0.80 \times(0.99+1.815 \times 9.81 \times 6.5) / 1.815 / 1000 \\
& =0.05 \mathrm{~kW}
\end{aligned}
$$

Where:

$$
\begin{aligned}
& P_{B}=\text { power required by gas blower }(\mathrm{kW}) \\
& \dot{r}_{\sim_{2}}=\text { mass flow rate of } \mathrm{CO}_{2}(\mathrm{~kg} / \mathrm{s}) \\
& \Delta P_{B}=\text { pump pressure required to transfer fluid or gas (Pascal); } \\
& \rho_{\mathrm{CO}_{2}}=\text { density of } \mathrm{CO}_{2}\left(\mathrm{~kg} / \mathrm{m}^{3}\right)
\end{aligned}
$$

Thus, the total power consumption for $\mathrm{CO}_{2}$ separation and CPCS is $401.64 \mathrm{~kW}$. The fuel oil consumed due to gas blower and membrane is 29.15 ton per voyage and the fuel cost is estimated to be $\$ 18,072.66$.

\subsubsection{Cargo penalty due to CPCS system application}

Table 8 lists the density and volume of the chemicals involved in CPCS. The total volume taken by the chemicals is $1,112.49 \mathrm{~m}^{3}$. The density of coal is $929 \mathrm{~kg} / \mathrm{m}^{3}$ so the mass of coal cargo in an equivalent volume is $1,033.50$ tons (Anval Valves Ltd.). According to the current coal shipping price15 \$/ton (ChinaCCM, 2013), the total cost of cargo freight penalty due to CPCS system application is $15 \times 1033.50=\$ 15,502.48$. 
Table 8 Volumes and mass of coal losses due to storage of chemicals

-- Insert Table 8 here --

\subsection{Profits made by selling by the product from CPCS system}

There are two parts of profits resulting from applying of the CPCS system:

a. Profit made from selling the final product of CPCS

b. Saving from carbon credits.

The final product from CPCS is $\mathrm{CaCO}_{3}$ (limestone) which is an industrial raw material widely used in many different industries, such as paper making, construction and plastic industries. The commercial price of limestone is $50 \$ /$ ton. The carbon credit is $15 \$ /$ ton based on the report of '2012 Carbon Dioxide Price Forecast' (Wilson et al., 2012). Thus, the profits made from selling $\mathrm{CaCO}_{3}$ and saving of $\mathrm{CO}_{2}$ credits are $\$ 85,603.23$ and $\$ 11,299.63$.

\subsection{Cost comparison between CPCS and liquefaction method}

Having conducted the above cost analysis, Table 9 is resulted to present costs and profits of CPCS in a comparison with the conventional liquefied $\mathrm{CO}_{2}$ storage method.

Table 9 Costs and profits comparison

-- Insert Table 9 here --

a: Negative sign means earning profits; b: Wischnewski; The physics hyper textbook, 1998; c: Melzer, 2012.

It can be seen that if the $\mathrm{CaCO}_{3}$ were sold at the destination of a voyage, applying CPCS can make

$\$ 35,981.07$ profit while capturing $20 \% \mathrm{CO}_{2}$ emissions from engine exhaust.

The operation cost and profit made from liquefaction method are listed in the table above. There are no chemical substances involved in liquefaction method so there is no cost due to purchase chemical substances. However, energy cost due to $\mathrm{CO}_{2}$ liquefaction processes is considerable referring to liquefaction cost in the table. The freight reduction is resulted from the storage of liquefied $\mathrm{CO}_{2}$. The 
profits are made from saving carbon credits and selling $\mathrm{CO}_{2}$ for enhanced oil recovery (EOR) which is about $25 \$ /$ ton (Melzer, 2012).

\section{Conclusions}

The laboratory experiment examined the impacts of four key factors in CPCS. The results show that the $\mathrm{CO}_{2}$ absorption rate varies with various parameters, such as solution volume, height, crosssection area and $\mathrm{CO}_{2}$ gas flow rate. The results provide an insight of CPCS effectiveness and offer a useful reference in onboard system design.

The comparative study between CPCS and liquefaction for CCS onboard ships has shown that the liquefaction method has a merit of low running cost. The CPCS method has a higher profit from selling the end product. The profit is sufficient to overweight the running cost and freight penalties. The study proves that, $\mathrm{CPCS}$ for marine $\mathrm{CO}_{2}$ capture and storage offers advantages of fewer requirements for captured $\mathrm{CO}_{2}$ storage and transportation; safety and stability of ship operation are not affected. It is a cost-effective method bringing profits every single voyage if the product of $\mathrm{CaCO}_{3}$ were sold. Conclusions can be made that the proposed chemical absorption processes for carbon dioxide solidification is a feasible and cost effective method for ship $\mathrm{CO}_{2}$ emissions reduction.

Further studies should be conducted to analyses the factors that could improve the $\mathrm{CO}_{2}$ absorption rate. Factors that can increase $\mathrm{NaOH}$ regeneration rate and filtration efficiency of $\mathrm{CaCO}_{3}$ should also be investigated and analyzed in order to increase the total efficiency of the system. To verify the results from experiment, Computing Fluid Dynamic (CFD) study is underway for system simulation and onboard system design. 


\section{Acknowledgment}

Authors are grateful to the Department of Naval Architecture and Marine Engineering of University of Strathclyde for the financial support on the project. We also appreciate the Scottish Environmental Technology Network for providing laboratory facilities and useful advices.

\section{References}

A., Aspelund, M.J., Mølnvik, G.D., Koeijer, 2006. Ship Transport of $\mathrm{CO}_{2}-$ Technical Solutions and Analysis of Costs, Energy Utilization, Exergy Efficiency and $\mathrm{CO}_{2}$ Emissions.

A., Witkowski, M., Majkut, 2012. The Impact of $\mathrm{CO}_{2}$ Compression Systems on the Compressor Power Required for a Pulverized Coal-fired Power Plant in Post-combustion Carbon Dioxide Sequestration, the Archive of Mechanical Engineering VOL. LIX, page 343-360.

Boden, T.A., G. Marland, and R.J. Andres., Global, Regional, and National Fossil-Fuel $\mathrm{CO}_{2}$ Emissions, Carbon Dioxide Information Analysis Centre, Oak Ridge National Laboratory, U.S. Department of Energy, Oak Ridge, Tenn., U.S.A. doi 10.3334/CDIAC/00001_V2010.

Bunker Price of Hong Kong, Marine Engineers Review, Institute of Marine Engineering, Science and Technology, November, 2013, page 38 .

Bulk Density Chart, Anval Valves Pvt Ltd.

E.C.S., Souto, J.J.R., Damasceno, C.E., Hori, 2008. Study of Operational Conditions for the Precipitated Calcium Carbonate Production, in: Materials Science Forum Vols. 591-593 (2008), pp 526-530.

Fresh Water and Seawater Properties, International Towing Tank Conference (ITTC), 2011, page 8.

H., Barthelemy, D., Bourdeaud'huy, J.-L., Jolivet, U., Kohl, K., Krinninger, D., Teasdale, A., Webb, S., Williams, 2010. IGC Doc 164/10/E: Safe Handling of Liquid Carbon Dioxide Containers that Have Lost Pressure, European Industrial Gases Association (EIGA) Aisbl.

HiMSEN Engine, IMO Tier II Program 2012, Marine \& Offshore GenSets, Marine Propulsion System Stationary GenSets, Hyundai Energy \& Machinery Heavy Industries CO. LTD. 
Houghton, J.T., 2004. Global Warming: The Complete Briefing. Chapter 3, Greenhouse Gases, Cambridge University Press.

IPCC, 2005: IPCC Special Report on Carbon Dioxide Capture and Storage. Prepared by Working Group III of the Intergovernmental Panel on Climate Change [Metz, B., O. Davidson, H. C. de Coninck, M. Loos, and L. A. Meyer (eds.)]. Cambridge University Press, Cambridge, United Kingdom and New York, NY, USA, 442 pp.

G., Barbieri, A., Brunetti, F., Scura, E., Drioli, 2011. $\mathrm{CO}_{2}$ Separation by Membrane Technologies: Applications and Potentialities.

J., Ciferno, J., Litynski, S., Plasynski, J., Murphy, G., Vaux, R., Munson, J. Marano, 2010. Carbon Dioxide Capture and Storage RD\&D Roadmap, Department of Energy and National Energy Technology Laboratory.

L.S., Melzer, 2012. Carbon Dioxide Enhanced Oil Recovery ( $\left.\mathrm{CO}_{2} \mathrm{EOR}\right)$ : Factors Involved in Adding Carbon Capture, Utilization and Storage (CCUS) to Enhanced Oil Recovery.

M., Mahmoudkhani, D.W., Keith, 2009. Low-energy sodium hydroxide recovery for $\mathrm{CO}_{2}$ capture from atmospheric airThermodynamic analysis, Energy and Environmental System Group, Institute for Sustainable Energy, Environment, Economy, University of Calgary, Canada.

Massey, B. S. and A. J. Ward-Smith, 2012. Mechanics of fluids. London ; New York, NY, Spon Press.

MEPC 60/WP.6, Prevention of Air Pollution from Ships, Communication with IPCC on $\mathrm{CO}_{2}$ Conversion Factors, Marine Environment Protection Committee, IMO, 2010

Pflug, I.J., Angelini, P., Dewey, D.H., 1957. Fundamentals of Carbon Dioxide Absorption as They Apply to Controlledatmosphere Storage, Department of Agricultural Engineering and Horticulture.

Project Guide of MAN Diesel Engine: MAN B\&W: S70MC-C7, 4th Edition, 2009, branch of MAN Diesel SE, Germany. R., Wilson, P., Luckow, B., Biewald, F., Ackerman, E., Hausman, 2012. 2012 Carbon Dioxide Price Forecast, Synapse, Energy Economics Inc..

Rogner, H.-H., D. Zhou, R. Bradley. P. Crabbé, O. Edenhofer, B.Hare (Australia), L. Kuijpers, M. Yamaguchi, 2007: Introduction. In Climate Change 2007: Mitigation. Contribution of Working Group III to the Fourth Assessment Report of the Intergovernmental Panel on Climate Change [B. Metz, O.R. Davidson, P.R. Bosch, R. Dave, L.A. Meyer (eds)], Cambridge University Press, Cambridge, United Kingdom and New York, NY, USA.

Safe Handling of Caustic Soda (Sodium Hydroxide), 2006. Japan Soda Industry Association. 
Second IMO GHG Study 2009, International Maritime Organization (IMO) London, UK, April 2009; Buhaug, Ø.,

Corbett, J.J., Endresen, Ø., Eyring, V., Faber, J., Hanayama, S., Lee, D.S., Lee, D., Lindstad, H., Markowska, A.Z., Mjelde, A., Nelissen, D., Nilsen, J., Pålsson, C., Winebrake, J.J., Wu, W., Yoshida, K.

Significant Ships of 2011: HYUNDAI TRUST: 180,000dwt Cape sized bulk carrier from Sungdong, p48-49.

\section{Web reference:}

Alibaba.com: http://www.alibaba.com/product-gs/445114514/Caustic Soda.html; $h$ ttp://www.alibaba.com/producttp/113123860/QUICK LIME.html; http://www.alibaba.com/product-gs/594411302/light calcium CaCO3.html?s=p. 12/12/2013

B., Wischnewski. Peace Software, http://www.peacesoftware.de/einigewerte/co2_e.html.12/11/2013

The Physics Hypertextbook: http://physics.info/heat-latent/. 12/12/2013

International ocean freight rate statistics, China Commodity Marketplace (CCM), 2013,

http://www.chinaccm.com/40/20131206/402204_1576181.shtml. 22/11/2013

Slaking and Causticising, Metso Fiber Karlstad AB, 2011,

http://www.metso.com/pulpandpaper/MPwFiber.nsf/WebWID/WTB-101115-2256F-

DE839? OpenDocument\&mid=71967A486FAB2F29C22575B00048DEBB\#.Ud0 7aXs5CA. 18/7/2013

Understanding CCS, What is CCS how does it work and why is it important, Global Carbon Capture and Storage Institute, http://www.globalccsinstitute.com/understanding-ccs/the-climate-change-challenge. 5/12/2012 


\section{Figures}

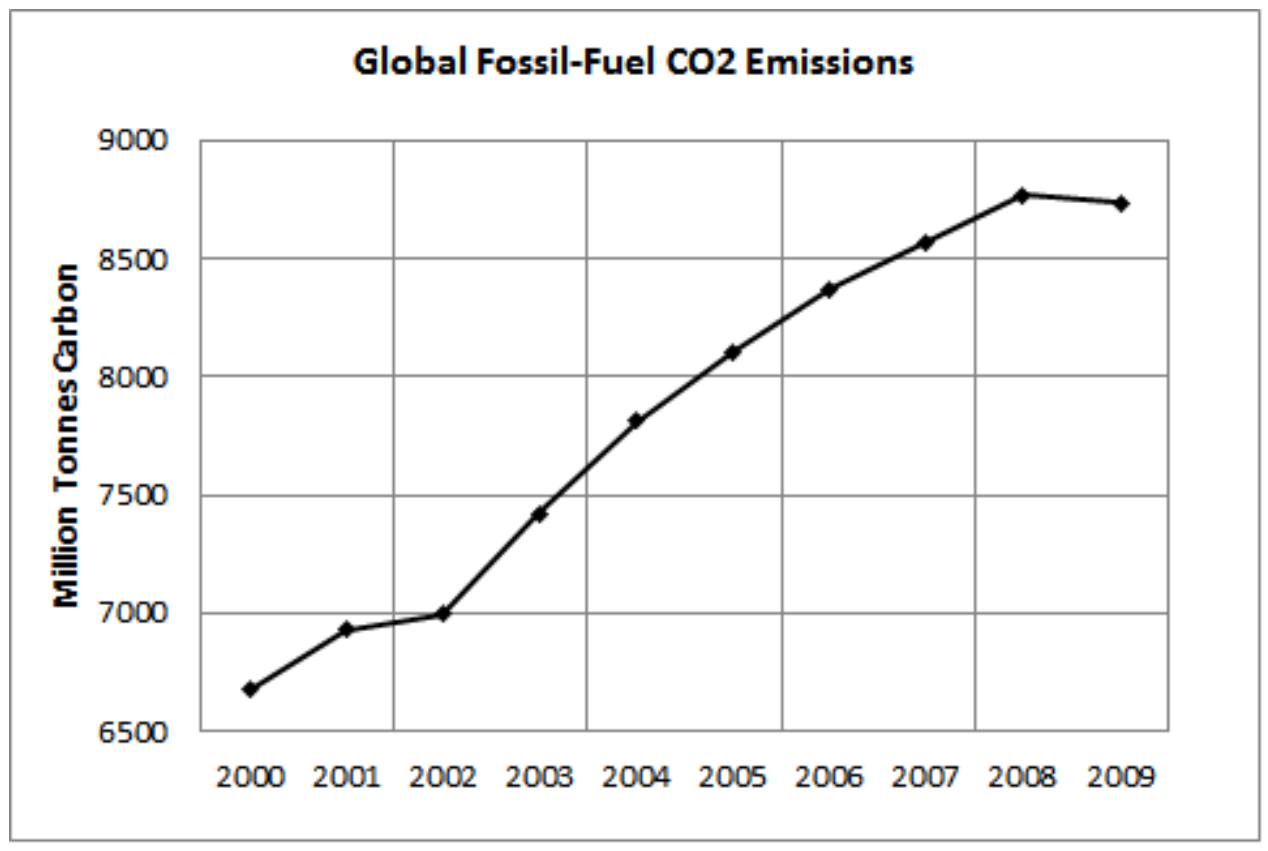

Fig. 9 Tendency of $\mathrm{CO}_{2}$ emissions from 2000 to 2009 

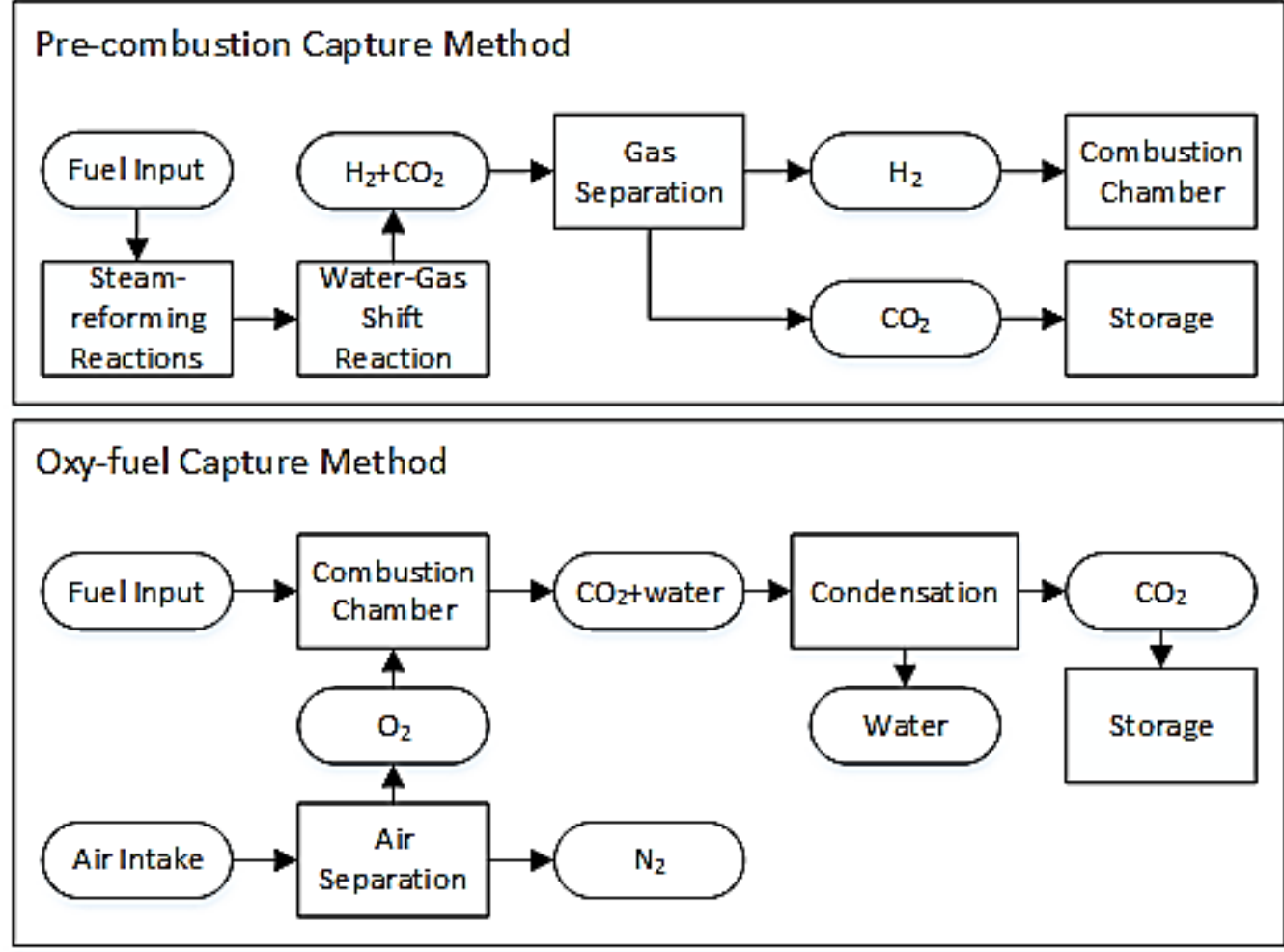

Post-combustion Capture Method

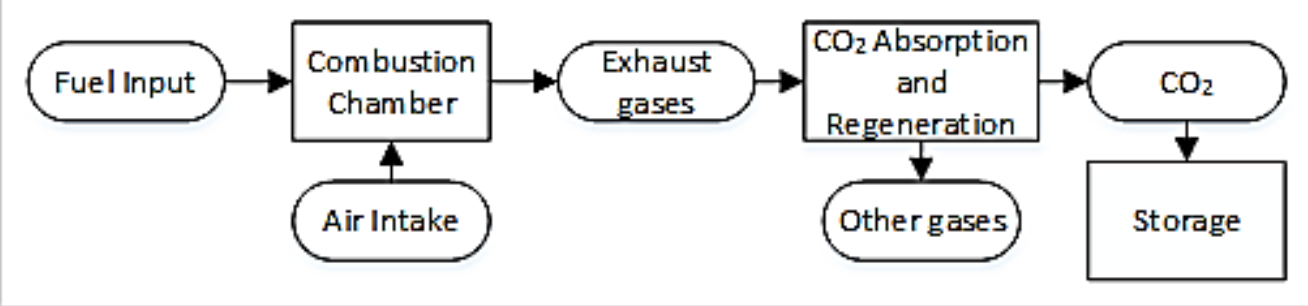

Fig. 10 General carbon capture methods 

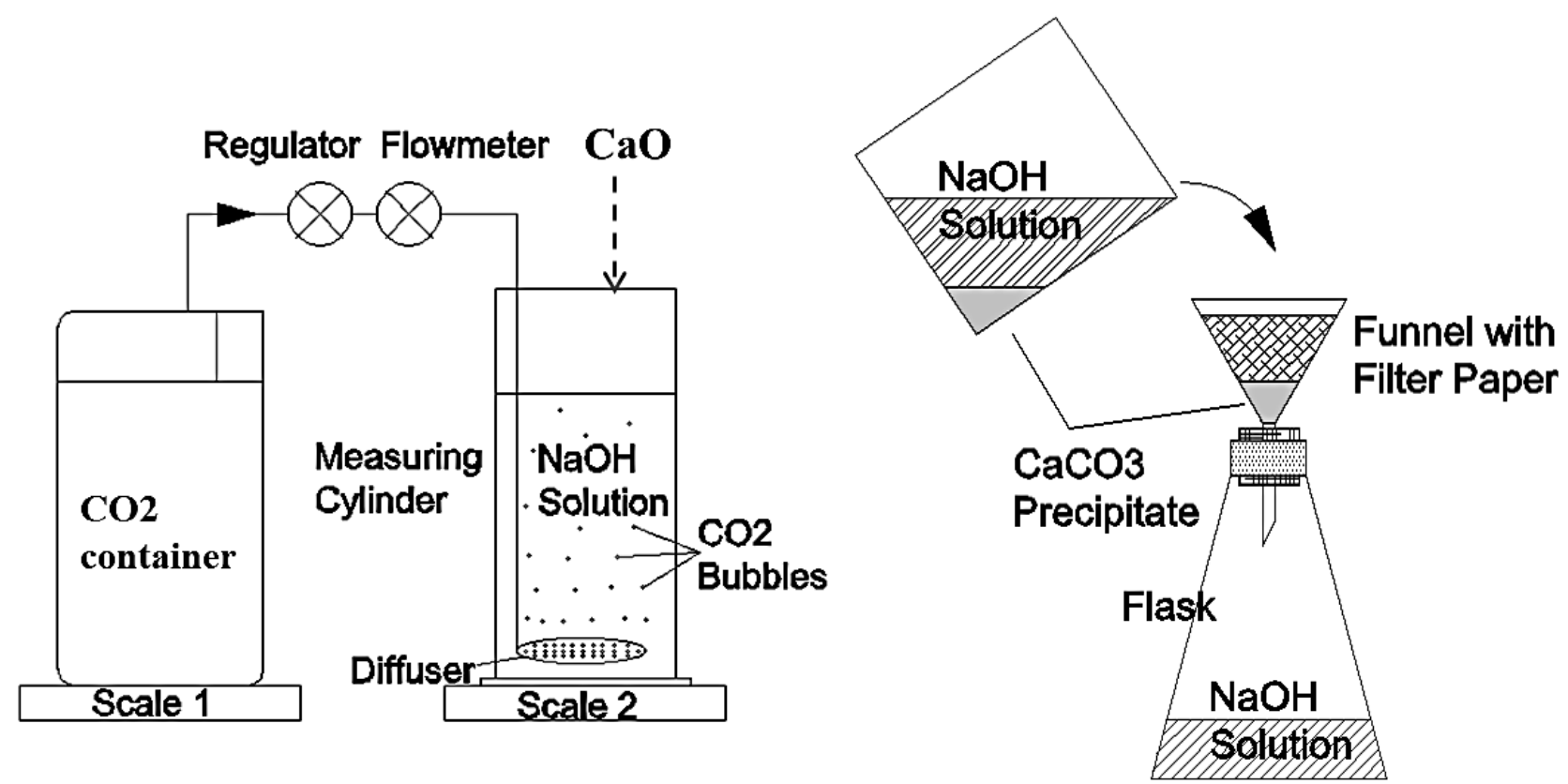

Fig. 11 Schematic of the experiment systems 

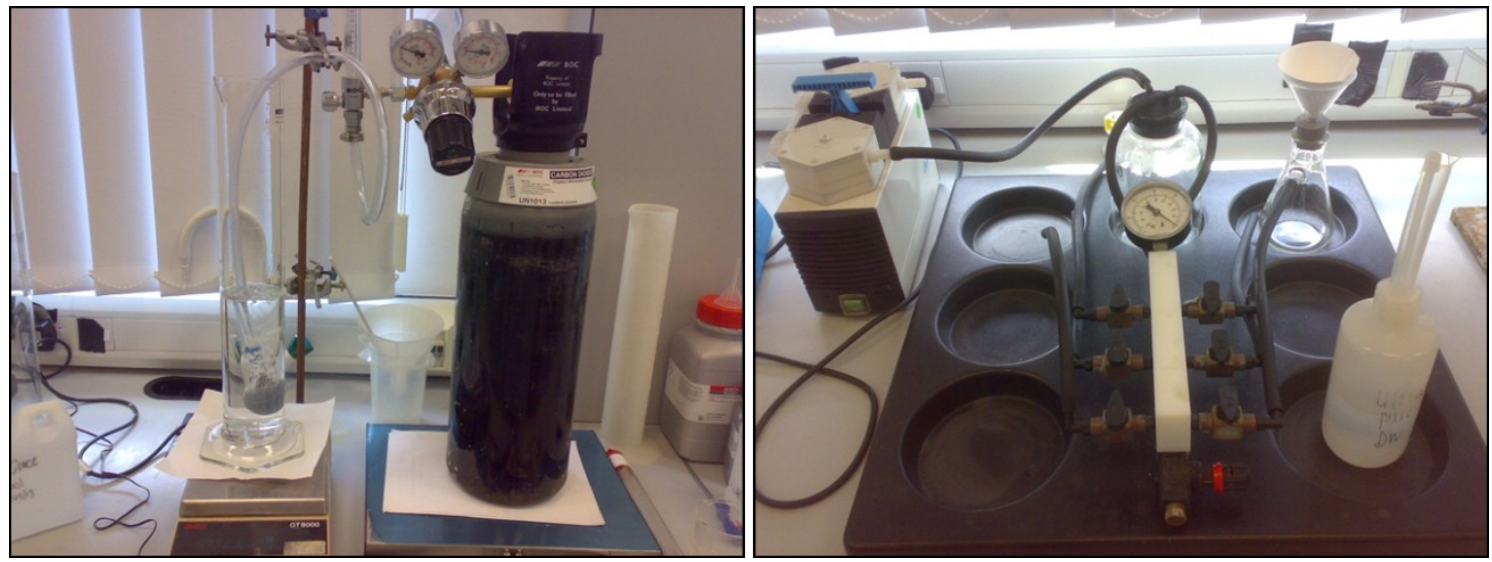

Fig. 12 Pictures of experiment rig 


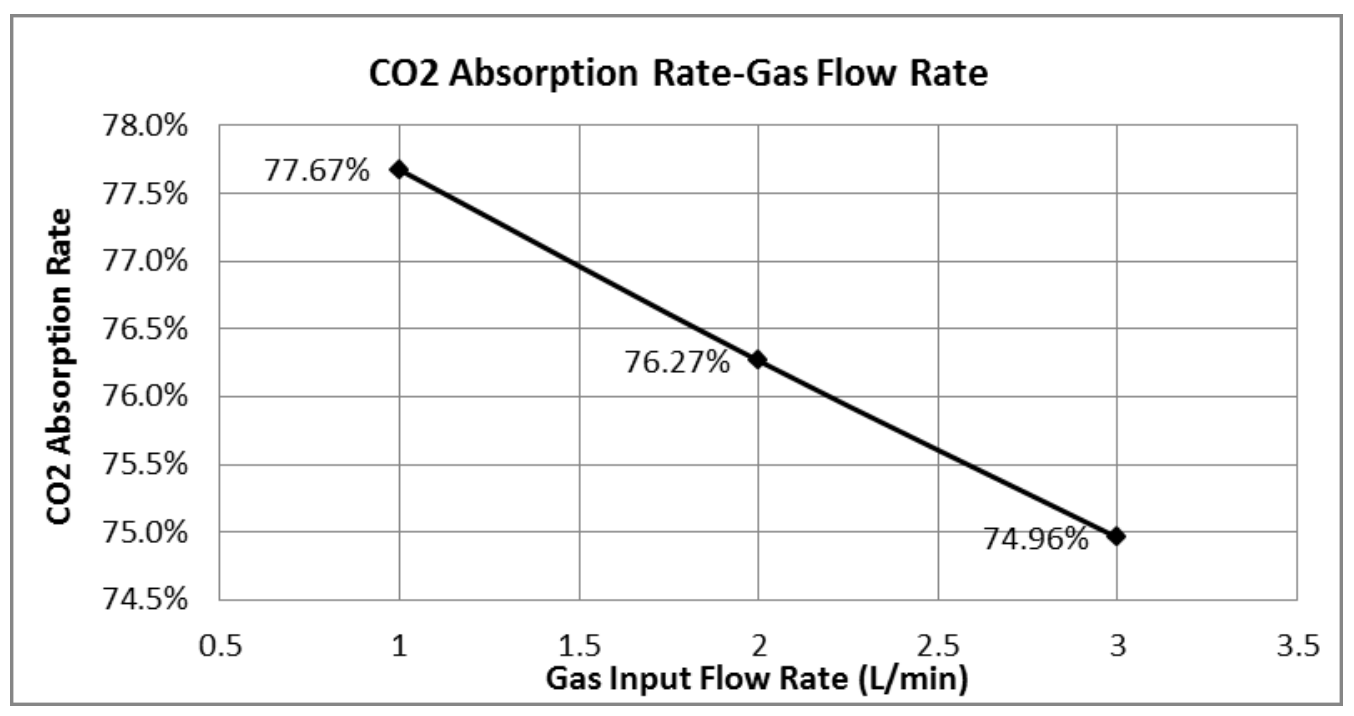

Fig. $13 \mathrm{CO}_{2}$ absorption rate vs. gas flow rate 


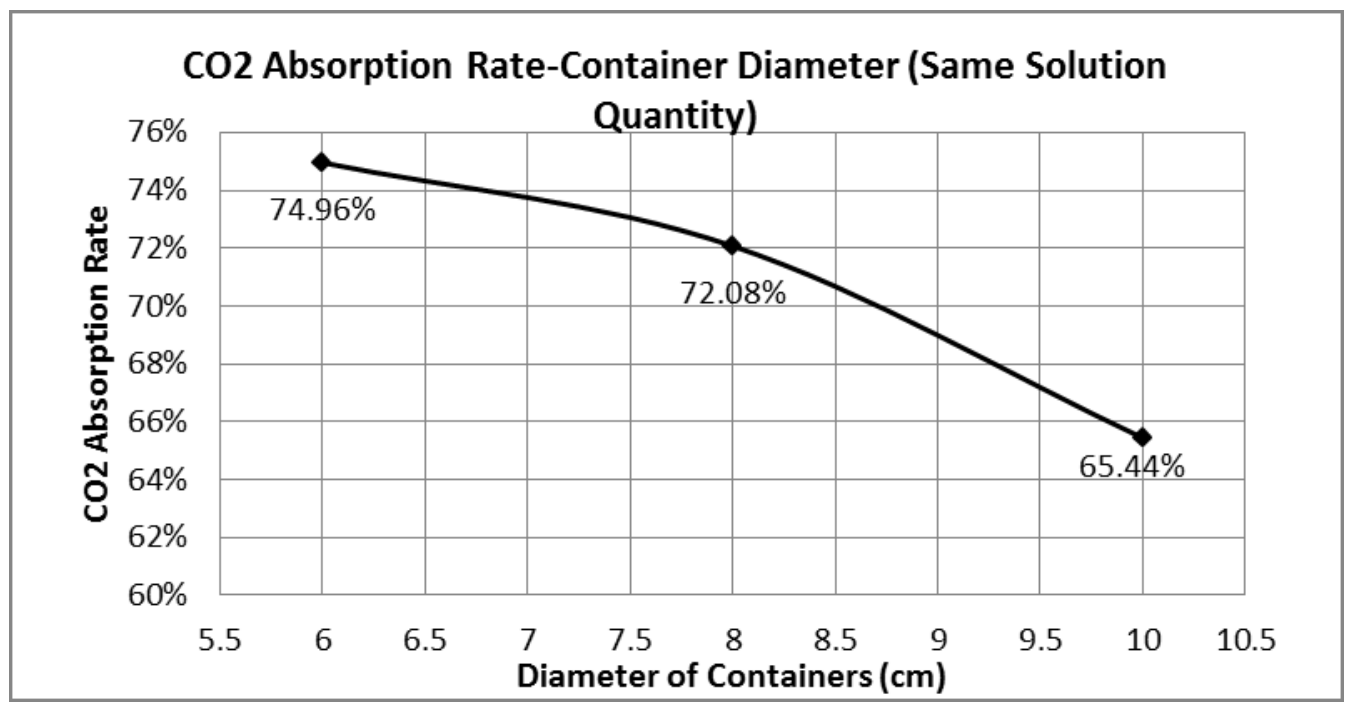

Fig. 14 Effect of container diameter on gas absorption rate with unchanged solution quantity 


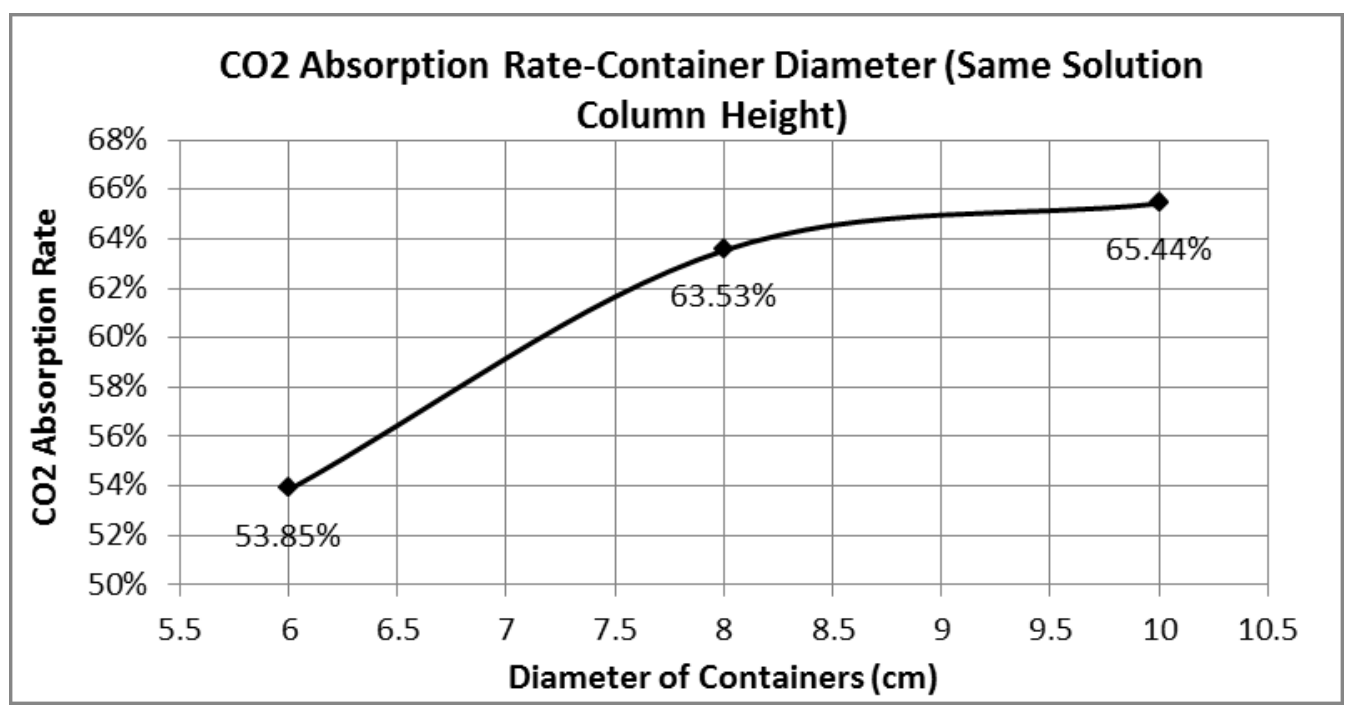

Fig. 15 Effect of container diameter on gas absorption rate with fixed solution height 


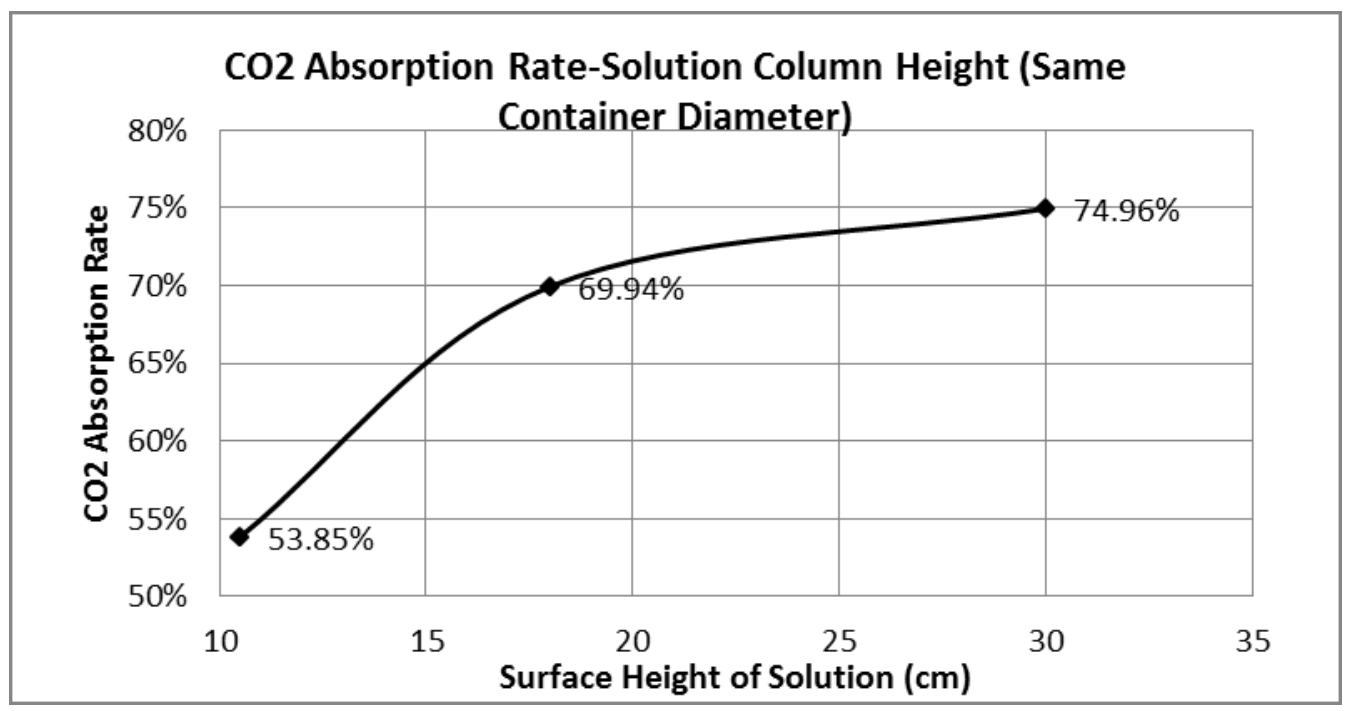

Fig. 16 Effect of solution column height on gas absorption rate with same cylinder diameter 


\section{Tables}

Table 1. Experiment results

\begin{tabular}{ll}
\hline Experiments Rates & Results \\
\hline $\mathrm{CO}_{2}$ Absorption Rate & $67.85 \%$ \\
$\mathrm{NaOH}$ Regeneration Rate & $85.37 \%$ \\
$\mathrm{CaCO}_{3}$ filtration efficiency & $82.17 \%$ \\
\hline
\end{tabular}

Table 2. Change of absorption rate with gas input flow rate.

\begin{tabular}{lllll}
\hline $\begin{array}{l}\text { Solution volume } \\
(\mathrm{ml})\end{array}$ & $\begin{array}{l}\text { Solution column } \\
\text { height }(\mathrm{cm})\end{array}$ & $\begin{array}{l}\text { Cylinder } \\
\text { diameter }(\mathrm{cm})\end{array}$ & $\begin{array}{l}\mathrm{CO}_{2} \text { Flow Rate } \\
(\mathrm{L} / \mathrm{min})\end{array}$ & $\begin{array}{l}\mathrm{CO}_{2} \text { Absorption } \\
\text { Rate }\end{array}$ \\
\hline \multirow{3}{*}{$\sim 900$} & \multirow{2}{*}{30} & 6 & 1 & $77.67 \%$ \\
& & 2 & $76.27 \%$ \\
& & 3 & $74.96 \%$ \\
\hline
\end{tabular}

Table 3. Changing of absorption rate with container diameters (solution quantity unchanged).

\begin{tabular}{lllll}
\hline $\begin{array}{l}\text { Solution volume } \\
(\mathrm{ml})\end{array}$ & $\begin{array}{l}\text { Solution column } \\
\text { height }(\mathrm{cm})\end{array}$ & $\begin{array}{l}\text { Cylinder } \\
\text { diameter }(\mathrm{cm})\end{array}$ & $\begin{array}{l}\mathrm{CO}_{2} \text { Flow Rate } \\
(\mathrm{L} / \mathrm{min})\end{array}$ & $\begin{array}{l}\mathrm{CO}_{2} \text { Absorption } \\
\text { Rate }\end{array}$ \\
\hline \multirow{3}{*}{$\sim 900$} & 30 & 6 & & $74.96 \%$ \\
& 18 & 8 & 3 & $72.08 \%$ \\
& 10.5 & 10 & & $65.44 \%$ \\
\hline
\end{tabular}

Table 4. Changing of absorption rate with container diameters (same solution column height).

\begin{tabular}{lllll}
\hline $\begin{array}{l}\text { Solution volume } \\
(\mathrm{ml})\end{array}$ & $\begin{array}{l}\text { Solution column } \\
\text { height }(\mathrm{cm})\end{array}$ & $\begin{array}{l}\text { Cylinder } \\
\text { diameter }(\mathrm{cm})\end{array}$ & $\begin{array}{l}\mathrm{CO}_{2} \text { Flow Rate } \\
(\mathrm{L} / \mathrm{min})\end{array}$ & $\begin{array}{l}\mathrm{CO}_{2} \text { Absorption } \\
\text { Rate }\end{array}$ \\
\hline 296.88 & & 6 & & $53.85 \%$ \\
527.79 & 10.5 & 8 & 3 & $63.53 \%$ \\
824.67 & & 10 & & $65.44 \%$ \\
\hline
\end{tabular}

Table 5. Change of absorption rate with solution column heights (fixed container diameter).

\begin{tabular}{lllll}
\hline $\begin{array}{l}\text { Solution volume } \\
(\mathrm{ml})\end{array}$ & $\begin{array}{l}\text { Solution column } \\
\text { height }(\mathrm{cm})\end{array}$ & $\begin{array}{l}\text { Cylinder } \\
\text { diameter }(\mathrm{cm})\end{array}$ & $\begin{array}{l}\mathrm{CO}_{2} \text { Flow Rate } \\
(\mathrm{L} / \mathrm{min})\end{array}$ & $\begin{array}{l}\mathrm{CO}_{2} \text { Absorption } \\
\text { Rate }\end{array}$ \\
\hline 848.23 & 10.5 & & 3 & $53.85 \%$ \\
508.94 & 18 & 6 & $39.94 \%$ \\
296.88 & 30 & & $74.96 \%$ \\
\hline
\end{tabular}


Table 6. Specifications of the case ship.

\begin{tabular}{|c|c|c|c|c|c|c|c|c|}
\hline \multicolumn{3}{|c|}{ Route details } & \multicolumn{3}{|c|}{ Vessel dimensions } & \multicolumn{3}{|c|}{ Engine and generator specifications } \\
\hline Origin & \multicolumn{2}{|c|}{ Port of Qinhuangdao } & Type & \multicolumn{2}{|c|}{ Bulk Carrier $^{\mathrm{a}}$} & $\begin{array}{l}\text { Main } \\
\text { Engine }\end{array}$ & \multicolumn{2}{|c|}{$\begin{array}{l}\text { MAN B\&W: 6S70MC- } \\
\text { C7 }\end{array}$} \\
\hline Destination & \multicolumn{2}{|c|}{ Port of San Francisco } & LOA & 292 & $\mathrm{~m}$ & $\begin{array}{l}\text { No. or } \\
\text { main } \\
\text { engine }\end{array}$ & \multicolumn{2}{|l|}{1} \\
\hline Range & 5,547 & $\mathrm{Nm}$ & LBP & 283.5 & $\mathrm{~m}$ & $\begin{array}{l}\text { Engine } \\
\text { Speed }\end{array}$ & 91 & $\mathrm{rpm}$ \\
\hline $\begin{array}{l}\text { Service } \\
\text { Speed }\end{array}$ & 15.2 & Knot & Breadth & 45 & $\mathrm{~m}$ & MCR & 18,660 & $\mathrm{~kW}$ \\
\hline \multirow[t]{6}{*}{ Duration } & \multirow[t]{6}{*}{16} & \multirow[t]{6}{*}{ Day } & Depth & 24.8 & $\mathrm{~m}$ & SFOC & 174 & $\mathrm{~g} / \mathrm{kWh}$ \\
\hline & & & Draught & 16.5 & $\mathrm{~m}$ & Generators & \multicolumn{2}{|c|}{ HHI/Himsen: 7H17/28 } \\
\hline & & & Gross & 94,360 & ton & $\begin{array}{l}\text { No. of } \\
\text { generators }\end{array}$ & \multicolumn{2}{|c|}{3 (1 stand-by) } \\
\hline & & & DWT & 157,500 & ton & $\begin{array}{l}\text { Engine } \\
\text { Speed }\end{array}$ & 900 & $\mathrm{rpm}$ \\
\hline & & & $\begin{array}{l}\text { Water } \\
\text { ballast }\end{array}$ & 78,000 & $\mathrm{~m}^{3}$ & Output & 780 & $\mathrm{~kW}$ \\
\hline & & & Fuel type & HSFO & & SFOC & 189 & $\mathrm{~g} / \mathrm{kWh}$ \\
\hline
\end{tabular}

Table 7. Quantities of substances consumption and costs.

\begin{tabular}{llll}
\hline Chemicals & Quantities (ton) & Unit price $(\$ /$ ton $)$ & Cost $(\$)$ \\
\hline Caustic soda $(\mathrm{NaOH})$ & 200 & $83.33^{\mathrm{a}}$ & 16,695 \\
consumed & 959 & 11.11 & 10,652 \\
Quicklime $(\mathrm{CaO})$ consumed & & & 27,347 \\
Sum & & & \\
\hline
\end{tabular}

Table 8. Volumes and mass of coal losses due to storage of chemicals. (Bunker Price of Hong Kong, November 2013.)

\begin{tabular}{lll}
\hline $\begin{array}{l}\text { Chemical } \\
\text { substances }\end{array}$ & Density $\left(\mathrm{kg} / \mathrm{m}^{3}\right)$ & Volume $\left(\mathrm{m}^{3}\right)$ \\
\hline $\mathrm{NaOH}$ & 2,130 & 94 \\
$\mathrm{CaO}$ & 3,355 & 286 \\
$\mathrm{CaCO}_{3}$ & 2,711 & 632 \\
$\mathrm{Sum}$ & & 1,112 \\
\hline
\end{tabular}


Table 9. Costs and profits comparison.

\begin{tabular}{|c|c|c|c|c|c|c|c|c|}
\hline \multirow{2}{*}{$\begin{array}{l}\text { Costs per } \\
\text { voyage }(\$)\end{array}$} & \multicolumn{4}{|c|}{ Operation costs } & \multicolumn{3}{|l|}{ Profits } & \multirow{2}{*}{$\begin{array}{l}\text { Total } \\
\text { costs }\end{array}$} \\
\hline & $\begin{array}{l}\text { Capture } \\
\text { cost }\end{array}$ & $\begin{array}{l}\text { Chemicals } \\
\text { cost }\end{array}$ & $\begin{array}{l}\text { Liquefaction } \\
\text { cost }\end{array}$ & $\begin{array}{l}\text { Freight } \\
\text { reduction }\end{array}$ & $\begin{array}{l}\text { Carbon } \\
\text { credits }\end{array}$ & $\mathrm{CaCO}_{3}$ & $\mathrm{CO}_{2}$ & \\
\hline CPCS & 18,073 & 27,347 & - & 15,502 & $-11,300^{\mathrm{a}}$ & $-85,603$ & - & $-35,981$ \\
\hline Liquefaction & 18,073 & - & $21,021^{\mathrm{b}}$ & 9,932 & $-11,300$ & - & $-18,833^{\mathrm{c}}$ & 6,758 \\
\hline
\end{tabular}




\begin{tabular}{|c|c|c|c|}
\hline \multicolumn{4}{|c|}{ Nomenclature } \\
\hline $\mathrm{CCS}$ & Carbon capture and storage & \multicolumn{2}{|c|}{ Chemical substances } \\
\hline CFD & Computing Fluid Dynamic & $\mathrm{Ca}(\mathrm{OH})_{2}$ & $\begin{array}{l}\text { Calcium } \\
\text { hydroxide }\end{array}$ \\
\hline CPCS & $\begin{array}{l}\text { Chemical Processes for Carbon } \\
\text { Solidification }\end{array}$ & $\mathrm{CaCO}_{3}$ & $\begin{array}{l}\text { Calcium } \\
\text { carbonate }\end{array}$ \\
\hline $\mathrm{D}$ & Diameter & $\mathrm{CaO}$ & Calcium oxide \\
\hline DWT & Deadweight tonnage & $\mathrm{CO}_{2}$ & Carbon dioxide \\
\hline EEDI & Energy efficiency design index & $\mathrm{CO}_{3}^{-}$ & Carbonate ion \\
\hline EEOI & Energy efficiency operational indicator & $\mathrm{H}_{2} \mathrm{O}$ & Water \\
\hline EIGA & European Industrial Gases Association & $\mathrm{Na}_{2} \mathrm{CO}_{3}$ & $\begin{array}{l}\text { Sodium } \\
\text { carbonate }\end{array}$ \\
\hline EOR & Enhanced oil recovery & $\mathrm{NaOH}$ & $\begin{array}{l}\text { Sodium } \\
\text { hydroxide }\end{array}$ \\
\hline GHG & Greenhouse gases & $\mathrm{NO}_{\mathrm{x}}$ & Nitrous oxides \\
\hline $\mathrm{H}$ & Height & $\mathrm{SO}_{\mathrm{x}}$ & Sulphur oxides \\
\hline HSFO & High sulphur fuel oil & & \\
\hline ICP & Inductively coupled plasma & \multicolumn{2}{|c|}{ Atomic and molar weight } \\
\hline IMO & International maritime organization & Carbon $(\mathrm{C})$ & 12 \\
\hline IPC & Inductively coupled plasma & $\begin{array}{l}\text { Hydrogen } \\
(\mathrm{H})\end{array}$ & 1 \\
\hline IPCC & Intergovernmental panel on climate change & Oxygen $(\mathrm{O})$ & 16 \\
\hline ITTC & International Towing Tank Conference & & \\
\hline LBP & Length between perpendiculars & $\mathrm{Ca}(\mathrm{OH})_{2}$ & 74 \\
\hline LOA & Length overall & $\mathrm{CaCO}_{3}$ & 100 \\
\hline M & Molar mass & $\begin{array}{l}\text { Calcium } \\
(\mathrm{Ca})\end{array}$ & 40 \\
\hline $\mathrm{m}$ & Mass & $\mathrm{CaO}$ & 56 \\
\hline MCR & Maximum continuous rating & $\mathrm{CO}_{2}$ & 44 \\
\hline $\mathrm{n}$ & Molar number & $\mathrm{H}_{2} \mathrm{O}$ & 18 \\
\hline $\mathrm{P}$ & Power & $\mathrm{Na}_{2} \mathrm{CO}_{3}$ & 106 \\
\hline $\mathrm{p}$ & Profit & $\mathrm{NaOH}$ & 40 \\
\hline $\mathrm{R}$ & Rate & $\begin{array}{l}\text { Sodium } \\
(\mathrm{Na})\end{array}$ & 23 \\
\hline SEEMP & Ship energy efficiency management plan & & \\
\hline SFOC & Specific fuel oil consumption & Units & \\
\hline $\mathrm{t}$ & Time & $\mathrm{L}$ & Litre \\
\hline V & Volume & $\mathrm{L} / \mathrm{min}$ & Litre per minute \\
\hline$\pi$ & pi & mol & Mole number \\
\hline$\rho$ & density & ppm & Parts per million \\
\hline
\end{tabular}

